FOLIA SCANDINAVICA VOL. 19 POZNAŃ 2016 DOI: 10.1515/fsp-2016-0009

DE DE GRUYTER OPEN

G

\section{PRESSto.}

\title{
CANONS AND CONTEMPORARY DANISH LITERATURE
}

\author{
ANNE-MARIE MAI \\ University of Southern Denmark
}

ABSTRACT. This article deals with recent Danish literature in the light of the discussion about canons occasioned by the publication of the two ministerial canons: Undervisningskanon (Educational Canon, 2004) and Kulturkanon (Cultural Canon, 2006). The article argues that recent Danish literature challenges traditional work categories and the concept of the author on which the two canons are based, and discusses which works and texts in recent Danish literature ought to belong to a future canon.

\section{THE CANON DEBATE}

During the first decade of the 21st century, two ministerial canons were published in an attempt to do something about the lack of knowledge on the part of Danes - and younger generations in particular about the Danish cultural and literary heritage.

Changing governments have felt that the collective memory is in a sorry state and have wished to strengthen knowledge of Danish literature by selecting a number of canonical texts and oeuvres, from folk songs to Klaus Rifbjerg.

The Educational Canon of 2004 and the Cultural Canon of 2006 were launched with both book publications, Internet presentations, debate meetings and new electronic resources, and the then Conservative minister of culture, Brian Mikkelsen, declared that the Cultural Canon was a compass that was to help readers get their bearings on their cultural heritage: 'It is a compass with an invitation to embark on Danish culture,' Mikkelsen (2006). The two canons gave rise to a quite a considerable comprehensive and heated debate and critique. Some people called them a piece of indifferent, sugary commercial, cf. Bredsdorff (2006); others pointed out that both canons suffered from 
a shocking lop-sidedness when it came to the number of women represented. Women writers almost completely disappeared from literary history. In the educational canon, Karen Blixen was the sole representative! ${ }^{1}$

The 'canon debate' made it abundantly clear that the works that survive in Danish literary history do so as part of a struggle and clash between opinions about and interpretations of both past and present texts and works. The canonical struggle is endless - works and texts can re-emerge after many years of absence, or be consigned to oblivion almost overnight.

The two ministerial canons have given rise to a number of considerations concerning the very nature of literary history. Johannes Fibiger, a senior teacher at a Danish sixth-form college, made an interesting contribution with his article 'The struggle for literary history', in which he wrote: 'The struggle for literature is thus an institutional one within the literary system as to who is to relate literary history and in what way. It has to do with power, means, prestige, influence, a view of method and subject matter, a view of history, etc. And linked to this level are also of course publishing interests and, in particular, prestige.' Fibiger (2006).

The two canons have to do with preserving a cultural heritage, but not - it should be noted - by reading the included works historically; rather by lifting the works out of history directly into the present, and reading the texts existentially and topically.

The canonical lists seek in this way to make the historical texts contemporary texts, and therefore the debates about the canons are not only a struggle about the literature of the past but also of the present day. The two canons are part of the struggle for recognition that is being conducted here and now and that is of importance for the handing down of contemporary literature. Which genres, themes and forms of expression are emphasised as

${ }^{1}$ The authors listed in the educational canon are: Folk songs, Holberg, Oehlenschläger, Grundtvig, Blicher, H.C. Andersen, Herman Bang, Pontoppidan, Johannes V. Jensen, Nex $\varnothing$, Tom Kristensen, Blixen, Martin A. Hansen, Seeberg, Rifbjerg. The canon has been altered from 1 august 2015, although these changes only apply to upper secondary education. The canon for the Folkeskole is as follows: Folkeviser, Holberg, Oehlenschläger, Grundtvig, Blicher, H. C. Andersen, Bang, Pontoppidan, Johannes V. Jensen, Nexø, Tom Kristensen, Blixen, Seeberg, Tove Ditlevsen, Henrik Ibsen. The texts of the cultural canon are the following: Leonora Christina: Jammers Minde [A Memory of Lament], written 1673-74, published 1869, Steen Steensen Blicher: Prasten $i$ Vejlbye [The Parson of Veilbye], 1829, H.C. Andersen : Den lille Havfrue fra Eventyr fortalte for Børn [The Little Mermaid from Tales Told for Children], 3rd booklet, 1837, Søren Kierkegaard : Enten - Eller [Either - Or], 1843, J.P. Jacobsen : Fru Marie Grubbe [Marie Grubbe - a lady of the 17th century], 1876, Herman Bang : "Ved Vejen", Stille Eksistenser [Katinka], 1886, Henrik Pontoppidan : Lykke-Per [Lucky Per], 1898-1904.Johannes V. Jensen: Kongens Fald [The Fall of the King], 1900-01, Karen Blixen: Vinter-Eventyr [Winter Tales], 1942, Klaus Rifbjerg: $O g$ andre historier [And other stories], 1964, Inger Christensen: Sommerfugledalen [The Valley of the Butterflies], 1991 as well as an anthology of poetry comprising 24 texts. 
being worthy of inclusion, and which ones glide into the background of the collective literary memory? The struggle for the canon of the future is being conducted here and now.

For that reason, it is relevant to discuss which texts and works in contemporary literature are artistically most worthy of inclusion and to point to literary quality in the plethora of individual works and oeuvres that exists. And in this connection it is a question of keeping one's eyes and ears open and not of simply prolonging the existing canon and identifying literary quality by means of what has already been accorded high status: the Bildungsroman, the classical short story and mainstream poetry.

Many of the forms of contemporary literary expression break with traditional work categories, literary genres and author roles, and if they are to become a part of the literary heritage, they must be brought into the fray in the canonisation process, which has its battlefields in the book review pages of newspapers, in periodicals, blogs and the social media as well as in the writing of literary history. If there is no broad reasoning or discussing of works and the literary value of texts in these fora, the end-result will be that the present period and important authors in it will not be included in the canon - as, for example, has been the case with female writers.

The past 50 years of Danish fiction constitutes a vast landscape of highly diverse literature in which it is hard to find one's bearings. The greatest problem is almost that there are so many good books around that it is difficult to find time to read and describe them before new books come along and call for readers' attention and that of the media. Furthermore, there is less column space than before for new publications. Another difficulty facing the many good literary texts is that the education system is not capable of including more than a handful of new texts per year, so that much of the very best literature never manages to reach textbooks and anthologies.

The great diversity is evident from the fact that new generations of writers emerge in the 1960s, 1970s, 1980s, 1990s, 2000s and 2010s, and that some of the older writers who made their debut as far back as the 1950s, headed by Klaus Rifbjerg, are still active and writing well into the first decade of the new millennium. Around 1965 comes the debut of a large group of writers who break away from the then predominant modernism of such authors as Klaus Rifbjerg, Jess Ørnsbo and Villy Sørensen, ushering in a new literary period in which we still find ourselves. We are dealing here with a formal breakthrough, where the nature of literature as form is thematised in many different ways. The formal breakthrough marks the start of a period that is still in the process of development, also in very young writers who are transforming both texts and their own roles as writers, cf. Mai (III, 2010).

When discussing a literary canon, one has to take into consideration that such a canon has until now been based on the idea that literary value is identical with clearly demarcated works originating from a single author. The canon concept is thus difficult to employ in relation to a period such as the present one, 
where genres overlap and interact, where the concept of the author is challenged by anonymous publications, joint projects and performative writer roles, and where the category 'literary work' is dissolving in a textual landscape of transient media and cross-aesthetical modes of expression.

\section{CHALLENGES MADE OF THE CANON CONCEPT}

Two challenges of the canon concept in the international literature of the past 50 years deserve closer attention. Firstly, European, American and Nordic literature all challenge the very category of a literary work; secondly, the concept of the author is also being challenged.

The many exciting crossovers of the period between artistic forms of expression are on the way to dissolving the concept of the work. The poet Peter Laugesen publishes collections of poetry almost annually that together make up one long cohesive stream of writing. It is actually difficult to choose one particular collection rather than another one. What we are dealing with here in Laugesen is not a work but a text, which to a greater extent is a process rather than a product. One possibility here could be to choose one of the many jazz-poetry videos that Laugesen has produced in collaboration with a changing team of musicians, but this means going beyond the book's boundary as a medium, even though the fusion between music, poetry and visual art clearly releases Laugesen's rhythmic poetry.

SMS texting literature by, for example, Svend Åge Madsen and Merete Pryds Helle will also find difficulty in being canonised because of the use of a digital medium, even though SMS texting short stories are a well-known international genre. The traditional canon concept prefers to have the book as its framework.

It would be even more difficult to canonise Gerd Laugesen's 'handkerchief and dress' poems, which move between visual art, performance and poetry. The poetry collection Har du set min kjole (Have you seen my dress, 2011) has been published with ten copies of a dress. One can also purchase the collection in a pocket that can be attached to one's clothing. 249 copies can been printed. Lommetørklaedesamlingen (The handkerchief collection, 2012) is a one-off collection that consists of 82 handkerchiefs with poems drawn on them.

A further problematising of the work concept is found in Asta Oliva Nordenhof, who works with book publications, blogs and facebook updates. She creates a distinctive convergence between the various media she makes use of; at times, her facebook updates take the form of small lyrical texts that are nevertheless difficult to locate in her today's status line, and it is really something of a challenge to clarify how one preserves and mediates these transient forms of expression. 
Secondly, contemporary literature challenges the concept of the author. A number of young writers seem to be withdrawing themselves and their works from the newspapers, periodicals and media of the public literary scene. This applies, for example, to Mikkel Thykier, who had his debut in 1997 with the highly praised poetry collection Skyggerne er kun flygtige (Shadows are only fleeting). Thykier wanted to publish his debut book anonymously, but Borgen Publishers refused to approve the idea, since when he has tried to find a way of publishing that can ensure that the literature can be a communication around the unknown rather than deal with identification and recognition of a writer persona. For him, the book is a residual product of a creative process, cf. Hansen (2013).

Many of his written works circulate among a circle of writers and critics and have gained a cult status, but they have never come to the knowledge of a larger public audience and are not accessible in the library system.

Nor does a recent work such as the shared publication Fri flet (Free braiding, 2014) by Mette Moestrup, Line Knutzon and Naja Marie Aidt, in which the authors appear anonymously as A, B and $\mathrm{C}$ with personal accounts and games - and also make use of many guest-writers - fit into the traditional canon, even though we are dealing with the most important feminist book since the documentary book Kvindernes bog (Women's book, 1972) by Jytte Rex and Inge Eriksen. The entire project makes one think of the philosopher Michel Foucault's 1960s' visions of a future anonymous circulation of discourses, in which one investigates how one can shape one's identity and one's humanity (Foucault, 1969). A number of Foucault's ideas can be traced in Fri flet. The difference, however, is that the three writers actually profile themselves personally in the shared writing project with its anonymous voices, and there is an indirect invitation to the reader to try and guess which is which. Present-day writers can disappear backwards out of the work or place themselves in front of it and almost overshadow it in a performative biographism, cf. Haarder (2014).

Most striking in this connection is Claus Beck-Nielsen, who has declared himself to be dead and buried, while at the same time, under other names and identities, he stands in the light of everything apart from precisely himself and his writer annihilation and resurrection project. The text have gradually come to resemble more and more a circumstance of his mental and physical transformation process. He has most recently re-arisen as Madam Nielsen, who is the author of the novel Den endeløse sommer (The never-ending summer, 2014), and he also appears both as Ophelia, Karen Blixen and Miss World. If the author's performative body is fused with his writing as the real art object, what chance is there of a canonisation? A stuffing of the author by a taxidermist would not be a solution, even though Nielsen would probably be prepared - in some years' time - to donate his body to such a project. 


\section{A CHANGING CANON}

\subsection{A MINIMALIST LINE}

As adumbrated, the concept of the canon is problematic. One can perhaps claim that literature is simply in the process of doing away with the canon, but when the struggle for literature and canon is still going on, and while a fragmentation of literature in the public eye increases, it nevertheless makes good sense to point out some of the best works and texts of the past 50 years. Literature can still be identified as the art of the word, also when it makes use of other media that the book, is included in crossovers between art forms and dissolves the concept of the author.

The two existing canons clearly prioritise the classic Bildungsroman, the event-centred short story and the mainstream poem. The literary ideals of the two canons are to be found in the prose of the modern breakthrough and in modernist poetry, which here make up the backbone of literary history. When it comes to the most recent works and authors, this means that one selected works and texts that fit these norms. Which in turn means that literary innovations after the modern breakthrough and modernism are toned down.

Klaus Rifbjerg is included in both the upper secondary Educational Canon and the Cultural Canon, the work chosen being his short stories Og andre historier (And other stories, 1961), which for years have supplied good material to Danish teaching. The stories excel in their use of point of view, breaking down of taboos regarding sexual themes and their metaphoric, and they definitely are a good candidate for a canonical text. But one could also point to the short novel Arkivet (The archive, 1967), which portrays some young men who have a student job in an office archive in the basement floor of a building. They are at a crossroads in their lives, at the intersection between young and adult life. There are still free of obligations and responsibility; they find themselves at an in-between stage in life, before real adult life, with a family and children, and after childhood and early youth. Death makes its entry into their lives for the first time when older members of the family pass away, but they are still unsure about the direction and aim of their existence and the very fixed bourgeois framework that seems to be waiting for them. The novel stands out for its minimalist narrative style, which in a very few sense perceptions and spoken lines illuminates their uncertainty and a vague longing. The novel uses the art of simplification in its portrayal of the young adults. Arkivet can also been seen as a counterpart to the Rifbjerg classic Den kroniske uskyld (Chronic innocence, 1958), which is vociferously metaphorical in its portrayal of postwar childhood and youth, and which has almost been read to matchwood in the service of Danish teaching. But with Arkivet we have a Danish 
contribution to the international minimalism of the 1960s from Ernest Hemingway and Raymond Carver to Paal-Helge Haugen, and if one had chosen this novel as a canonical text, one would have underlined the American media-realistic line in Rifbjerg's enormous oeuvre and his central position in contemporary literature as well. ${ }^{2}$ On the basis of Arkivet, one can also draw a line to another contemporary writer, Anders Bodelsen, who in his collection of short stories Drivhuset (The greenhouse, 1965) depicts with filmic realism the welfare state life that is in the process of developing. So far, Bodelsen has been a no-go on the canonical lists because of his popular bestseller crime fiction and mutual antagonism between him and Klaus Rifbjerg. But even though the two clashed head-on with each other in public back in the late 1960s, their books and texts can profitably be compared with each other, and it is high time to recognise the qualities present in Bodelsen's early short stories. Drivhuset portrays threshold experiences between childhood, youth and adulthood. In Bodelsen, individuals take part in a social interaction where welfare and material progress seem to represent a bonus and winnings, and where they can become what they choose to be. The woman in the short story 'Pointen' (The Point) from Drivhuset, who moves with her family to a new dwelling, is unable to find a unifying image of her existence in the flat and the years she leaves behind her. All she fins in the empty flat is an old heating account. Subsequently, a canonical line could be drawn from Rifbjerg and Bodelsen up to the writing of Helle Helle and her minimalism, as for example in the stories Biler og dyr (Cars and animals, 2000), which also thematises human life on the threshold between ages, self-perceptions and life-forms, and which adds a quite distinctive humour to minimalism.

A canon can thus change and become more richly faceted if one does not consistently prefer classics from Danish teaching in schools, but instead steps slightly outside and chooses other texts than the habitual ones. This could also be profitably be done with Peter Seeberg's oeuvre.

Like Klaus Rifbjerg, Peter Seeberg appears in the Educational Canon, where no texts are listed, only authors. Peter Seeberg is an obvious choice for practically any literary canon; he makes his debut in 1956 with the novel Bipersonerne (The secondary characters). It is, however, not until the 1970s and 1980s that he finds an original voice that innovates prose with a whole series of publications. In this connection, he is related to St. St. Blicher, gaining inspiration from European modernism and postmodernism from Friedrich Nietzsche to Albert Camus, Samuel Beckett and the linguistic philosopher Ludwig Wittgenstein in creating an existential, philosophical prose that inspires a number of other writers from Henning Mortensen to Hans

\footnotetext{
${ }^{2}$ The concept of media-realism is formulated by Frits Andersen in his portrait article on Rifbjerg, Mai II (2001).
} 
Otto Jørgensen and Peter Adolphsen. Seeberg's most important work from the 1970s is his novel Ved havet (By the sea, 1978), which takes place on a day in summer on the west coast of Jutland. The novel challenges the genre and deals with the difficult philosophical problem as to what time actually is, since it relates how a number of very different persons of experience themselves and the sea. We meet German tourists, soldiers who do a parachute jump, and fat sweaty women as well as children who argue and play. Ved havet is structured via the indication of various points of time and forms a literary and temporal topography that reaches into forms of experience where time mysteriously disappears or maybe opens up, cf. Andersen (2005). It is a philosophical realism that also lifts the many modern characters with their various different ages and times of life and work into another, larger time.

Among the older writers who made their debut before 1965 and who still publish in the period from 1965 to the end of the 1990s and who, despite his many literary qualities, has never been mentioned in connection with the two canons and who seldom feature in the teaching anthologies is Christian Skov. His short novel Høstnatter (Autumn nights, 1994), which was short-listed for the Nordic Council Literature Prize and was praised to the skies, deals with the life of the old peasant culture and its disappearance - one of the most recurrent themes of 20th century literature. The theme was introduced in masterly fashion by Henrik Pontoppidan, Johannes V. Jensen and Marie Bregendahl, and later renewed by such writers as Jørgen Nielsen and Albert Dam. The thematic also features in sovereign style in a number of recent works, especially the Ida og Axel-trilogi (Ida and Axel trilogy, 2001-07) by Hans Otto Jørgensen, which deals with the changes that take place in the peripheral areas of Denmark in the 20th century, Markedage (Special days, 2007) by Jens Smærup Sørensen and Mindet (The Memory, 2005) by Vibeke Grønfeldt, all three of which must be regarded as potential classics of contemporary literature. Smærup breaks up the Bildungsroman by following various family members on important special days in the family's life, and this new technique adds an existential scope to the theme. Vibeke Grønfeldt, in her novel about the farmer's daughter, Agate, uses a sensual, impressionistic style of writing. The novel is one of the series of four volumes about Agate. It concluded in 2011 with the novel Livliner (Lifelines), which portrays Agate's life in the rustic world that ends up as a periphery of Denmark.

If one thus attempts to include the minimalist and media-realistic tendencies of the past 50 years of literature, philosophical prose and the thematic of the disappearance of the old peasant culture, new works and oeuvres become relevant candidates for canonisation. It is striking that the canon does not include a single text that deals with the disappearance 
of the peasant culture. Official canonical literature takes place in the past, in the town and in the imagination - not out in the dying world of the back of beyond.

\subsection{MAINSTREAM POETRY AS THE SOLE CANDIDATE}

Unlike Seeberg, Per Højholt is included in the Cultural Canon, but not in the Educational Canon. Selected is one of his late, mainstream poems 'Person på toppen' (The person at the top, 1989), instead of giving on of his books and experiments of the 1960 s a canonical life. ${ }^{3}$ Such a choice is patently wrong, since his books from the 1960s are the most epoch-making and influential. Højholt's Min hånd 66 (My hand 66) is particularly worth mentioning, because here Højholt breaks away from the image-saturated confrontational modernism of Rifbjerg and Jess Ørnsbo and gives poetry a new humour and cognitive challenge. Min hånd 66 abandons a metaphysical nature and body metaphoric and adopts the form of concrete working with the language that includes thoughts on the relation between language and reality. The book is also, by the way, provided with a vinyl record with readings by the writer. More than one media interact as far back as 1966, cf. Mai (1994).

Inger Christensen is also included in the cultural canon because of her work Sommerfugledalen (Valley of the Butterflies, 1991), a sequence of sonnets that focuses on the individual's meeting with death. The work which is Inger Christensen's most important and innovative, however, is her large creation poem Det (It, 1969), which helps to promote a budding system poetry and a modern, socially critical poetry. In the poems of Det she depicts the establishing of a new therapy society and a new urban and work life that leaves little room for what is human and for the strong longing for freedom that the poet expresses.

Henrik Nordbrandt, as mentioned, features in the Cultural Canon with the title poem from his collection Violinbyggernes by (The city of violinmakers, 1985). The canonisation of precisely this poem means that one interprets Nordbrandt as a mainstream modernist who fits in well with a long line of mainstream poems in Danish literature from Holger Drachmann's 'Jeg hører i Natten den vuggende Lyd' (I hear at night the rocking sound) and Sophus Claussen's 'Ekbáta' to Morten Nielsen's 'Øjeblik' (Moment), Ole Sarvig's 'Regnmaaleren' (The rain gauge) and Per Højholt's 'Personen på toppen' (The person at the top) - poems that are all included in the Cultural Canon.

\footnotetext{
${ }^{3}$ In his thesis, Drømme og dialoger. To poetiske traditioner omkring 2000 (Dreams and dialogues. Two poetical traditions around 2000, 2009) Peter Stein Larsen discusses a mainstream poetric tradition with roots in symbolism and modernism, and an interaction poetry that is inspired by prose and the avant-garde. His definitions are useful, but it must be emphasised that the so-called interaction poetry comprises a whole range of different types of poetry. The history of poetry is many-stringed.
} 
But, deprived of the context in which the poem figures, one cannot actually understand the both ingenious and self-parodying tone of the poem 'Violinbyggernes by'.

Read in conjunction with the other poems of Violinbyggernes by, it is clear to what extent the poet is struggling to liberate himself from his fine love rhetoric, to brutalise it - indeed, to completely renounce it. The poet is taken up with the moments where such rhetoric fails, the union does not take place and his distraction leads in a completely new direction. The poet hopes to be transformed from being a prince and eloquent king's son, $r$ la Sophus Claussen, into a croaking frog. The poet senses that poems that are so playfully light become completely perfect by means of their reference to the mythology of Antiquity, poetic tradition and predecessors; words would seem to be able to be replaced as easy as pie; but it is the resistance of language, the breaks and the body, bones and nails and the wind music played at his own funeral that preoccupies the poet.

So it is the collection as a whole that indicates the linguistic problematic of the title poem, and that can illustrate Nordbrandt's paradoxical and emphasised poetry as one of the highlights of the period.

Henrik Nordbrandt belongs to the generation of mid-1960 poets that is ignored by both the Educational Canon and the Cultural Canon. We are dealing here with a whole series of writers who have their debut around 1965-67 and who find themselves at the intersection between the ramifications of modernism and an experimental art of words that has its precursors in American beat poetry and minimalism, in jazz music and European concretism.

While Nordbrandt writes in an extension of late-symbolism, Dan Turéll's poetry belongs to beat and jazz poetry. What, however, the two writers perhaps share is a longing to get the familiar poetic rhetoric from symbolism and modernism to go beyond itself, and at the same time to express an almost ZenBuddhist experience of a mysterious cohesion or wholeness. 'I demand a whole death', Nordbrandt says in his poem 'Instrumenter' (Instruments). Dan Turéll approaches something similar - lengthy literary ragas and repetitions, approaches what he referred to as the meaningless cohesion of all things, and improvisatory juxtaposition of big-city voices, situations, stories and genres.

An obviously canonical book in Dan Turéll's oeuvre is Karma Cowboy (1974), in which Eastern and Western philosophy, high-brow and low-brow literature and culture, English and Danish language are mixed into a poetic pot pourri about 'the melting time of a new body' and the instantaneous openness of the world.

While Nordbrandt lets his metaphors swirl around inside the linguistic framework of Danish, Dan Turéll shares his idea of opening up poetry to all kinds of themes, voices, language use and modes of expression with Klaus Høeck and Peter Laugesen. 
Høeck's potentially canonical work Hjem (Home, 1985) is an encyclopedia of the Danish outside world, and the text has quite literally been created out of the formulae for the Danish subsoil. Part of the text actually 'speaks in tongues' in the distortion of language resulting from the formal system, and the three tracks: Nature, Spirit and Culture, weave in and out of each other in a total composition: Nature is read from left to right, Culture from right to left, and Spirit radially.

The work unites prose and poetry in the narrative of the poet's profound grief at the suicide of his beloved and of how he struggles, like an Orpheus, to bring her back from the realm of the dead.

Hjem places itself in an old tradition that has roots in the creational poetry of the medieval and renaissance period, a tradition we know in Denmark from Anders Arreboe's Hexaëmeron, about the six days of Creation, as well as in completely new, cybernetic poetry. The result of this rigorous control, paradoxically enough, is a completely new freedom to pursue subjects and themes and to get language to stretch itself into an unknown totality of meanings and conceptions. Here poetry is made out of pig's hearts in a creamy sauce, slaughterhouses, fragrant roses, seasons, Denmark's lovely bridges, power plants and public offices.

Peter Laugesen also cultivates a linguistic and thematic opening up of poetry. His poetry, as one of the titles of his books indicates, is like a kind of river writing. Per Højholt described his books as 'The annual letter from Peter' so as to underline the continuity and the unmistakable poetic voice that characterises the entire opus. Laugesen's poetry never stands still, the words reach out after each other and into the next text or book.

It is difficult to point to canonical works in an oeuvre, but here one could choose such a book as Konstrueret situation (Constructed situation, 1996), where the writing becomes a counterpart to the fossilising of the state of society and political thought into power and self-justification, and in which puppies, birds, insects and toads tumble around in the construction of the poems and make it playful and light. The concept constructed situation has been inspired by discussions in the Situationist International (SI) that Asger Jorn helped to found along with the French philosopher and film-maker Guy Debord. In the SI manifesto, the 'situation' is called an invitation to play and an organisation of the living moment. Laugesen states that the poem is 'the trick of realising art' (Mai \& Borup, 1999: 254 ff.), and his poems can be read as constructed situations. Precisely the collection of the same name has both short and slightly longer texts, including Japanese poetic forms. There is also an alternation between small, metaphorical poems and rhetorical, intoned, narrative texts that mention many of Laugesen's literary kindred spirits and inserted quotations. Capital letters and self-ironical gestures are mixed into the stream of writing that sometimes become dense and concentrated as in the following: 
The night is red as a goat.

The night is ever-roaming just look at the stars dammit.

The night is a peevish teenager

That says you are pissing senile.

The night lives in your mother's opera glasses.

(Laugesen, 1996:13)

One could also choose the publication by Peter Laugesen and the Group Singvogels Den her planet glemmer vi aldrig (We'll never forget this planet, 2011), in which texts from a number of Laugesen collections become spoken words. The album is also accompanied by a video for the number 'Strisserne breder sig' (The cops are spreading), which can be seen on You-Tube.

A third canonical mid-1960s debutant is Johannes L. Madsen, whose poetry is as a rule omitted from teaching anthologies. The strongly modernist influence on Danish literature from Ole Sarvig to Klaus Rifbjerg went off onto a side-track in the period that immediately followed after it, but Johannes L. Madsen's amusing and critical surrealism is the most original contribution to concretism that Danish literature has on offer.

\subsection{POETRY'S NEW VINTAGES}

The many poets of the mid-1960s and the new poets of the 1970s, headed by Vita Andersen, were of importance for the following generations in the 1980s. A number of the poets from the 1970s and 1980s have gained a foothold both in Danish teaching and in many anthologies. Single texts are operated with, but if one were to highlight entire oeuvres, one could mention Vita Andersen's Tryghedsnarkomaner (Safety addicts, 1977), Michael Strunge's last publication Verdenssøn (Son of the World, 1986), which displays painfully and beautifully his poetical gamut, F.P. Jac's Misfat (1980), which in its own way expresses the energy and linguistic imaginativeness of the poetry of the early 1980s, Søren Ulrik Thomsen's City Slang (1981), in which the rhythms of the body, the poem and the city interweave, and Pia Tafdrup's prize-winning poetic work Dronningeporten (The Queen's Gate, 1998), which resoundingly makes use of the symbolic body-poetic that has been the distinctive hallmark of her work since her debut in 1981.

The poetry of the 1980s had many successors from the middle of the decade onwards into the 1990s. Texts by Niels Frank, Thomas Boberg, Simon Grotrian and Mette Moestrup all have qualities that entitle them to become canonical, but it is still difficult to point precisely to which of their works would make the most obvious choices - and new books to choose between are constantly being added. 
Niels Frank, for example, has published both excellent poetry, text books and essays, but the essay genre is harder to keep in the readers' and mediators' focus than poetry. Thomas Boberg publishes both poems, novels and prose travel accounts, but it is hard to decide which part of his oeuvre is strongest. Perhaps it is his socially critical poems in Hestecederne (The horse-eaters, 2010), where one notices the long, surrealist lines in what is gradually becoming a quite comprehensive oeuvre.

The period around the turn of the millennium has produced completely new poets who distance themselves from the poetics of the 1980s and 1990s and are linked to a greater extent to the experimental, genre-challenging sides of international poetry in the 1960s. Lars Skinnebach and Ursula Andkjær Olsen could possibly be among the new canonical writers. Lars Skinnebach's Enhver betydning er også en mislyd (Every meaning is also a dissonance, 2009) renews both a poetry with a political tendency and experiments with various genres. Ursula Andkjær Olsen's Egteskabet mellem vejen og udvejen (The marriage between the way and the way out, 2005) continues to explore the idea of including the whole gamut of language in poetry and of creating an alternation between various discourses and text forms. The book is practically unreadable if one starts at the beginning. As a reader, one has to hop from one section to another and between sequences to get an idea of the rhythm of the book.

A certain classic, however, is Yahya Hassan's Digte (Poems, 2013), in which a young Danish-Palestinian man displays a strong, lyrical voice. The poet grew up in the ghetto, and was exposed to the hard-handed treatment of a patriarchal and religiously hypocritical father as well as to the failure and lack of understanding of the welfare institutions. The poetry collection broke down a taboo with its expressionist interpretation of brutalisation in the ghetto. The poems made it possible to have a dialogue about relations in a welfare society that within certain areas seem to be powerless to deal with abuse and hatred. Hassan's poems positioned themselves in a series of classic works about the lifeexperiences of a young generation that stretches from Gustaf Munch-Petersen, Sonja Hauberg and Morten Nielsen to Michael Strunge.

The potential classics of the most recent period include a number of Danishlanguage lyrics and rap texts. Literature breaks out of the book medium and spreads out as poetry and the art of words in other media and genres. Rock poetry, in a Danish context, includes classics by Eik Skaløe, C.V. Jørgensen, Steffen Brandt, Peter A.G. and Michael Falch. Eik Skaløe's classic is 'Itsi-Bitsi' from Steppeulvene's legendary Hip, 1967. Skaløe imagined he would have a life more as a poet than a musician, but his early death in 1968 marked a sudden end to his career.

C.V. Jørgensen's songs have sharp-edged images of neon, night, dream and a dark winter, which is in line with the iconography of poets of the 1980s, while Steffen Brandt's critical and narrative lyrics can be read together with 
Dan Turéll's and the mid-eighties poets' preoccupation with everyday language. Among the rap texts, Den gale pose's 'Definition af en stodder' (Definition of a blighter) - which refers to Holberg, who in his age referred to poets as blighters - has become a classic, along with texts by Malk de Koijn such as 'Jernskjorten' (The iron shirt, 2002), which resembles an updated version of the thematisation of body, urges and childhood in Klaus Rifbjerg back in 1956.

There is canonical quality to be found in contemporary poetry, song lyrics and rap. The openness towards every kind of impulse and inspiration from literature, philosophy and art which makes a serious impact from the mid1960s onwards really helps to imbue such writing with a curiosity about everything that is human and a courage to innovate poetic language.

\subsection{PROSE RENEWALS}

Peer Hultberg made his debut in 1966, the same year as Henrik Nordbrandt, Dan Turéll and Klaus Høeck. He is definitely worth taking up cudgels for when it comes to canons and literary histories, for, like Smærup Sørensen, Kirsten Thorup and Svend Åge Madsen, he renews the novel genre. Hultberg experiments with voices and viewpoints, while still retaining the ability to tell good stories. His canonical book could be Byen og verden (The city and the world, 1992) a book about people, events and intrigues in the city of Viborg, all of it depicted in 100 small pieces of prose that take the reader through the entire 20th century.

Hultberg's medium is the written book, but the narrative is chatty, gossipy and loquacious - a cacophony of voices, prejudices, tragedies and hopes, a sound picture from a changing city.

The desire to look back or, for that matter, forwards in time and, in general, to write in an existential and philosophical manner about the problematic of time and the narrative - as does Peter Seeberg - is characteristic of Svend Åge Madsen, who had his debut at Arena, where Peter Seeberg was a central figure. In various ways, Madsen has cultivated a systematic, mathematically based prose that can both take the form of experiments with concrete poetry and as a development of large narrative structures. The latter takes place in the main work Tugt og utugt $i$ mellemtiden (Castigation and fornication in the meantime, 1976), which takes place in Aarhus around 1975. Ludvig Alster, unjustly condemned for murder, returns to the city as an avenger to settle the score with those who were responsible for the miscarriage of justice against him. The novel is told from a future perspective in which the narrator looks back and the intervening period, which took place historically speaking in the 1500-2000 period. Aarhus becomes a locus mundus for many different kinds of adventures and fictions, and Madsen freely unlocks the treasure trove of 
all great storytellers and popular writers. Fyodor Dostoyevsky, Alexandre Dumas, Eugéne Sue and Franz Kafka are within mental reach, along with Søren Kierkegaard and Karen Blixen.

Like Svend Åge Madsen, Kirsten Thorup - who had her debut in 1967 also works both with the minimalist art of words and large, complex narrative works. Her novel series about Lille Jonna (Little Jonna, 1977-87) is one of the highlights. The series tells both the large-scale, realistic history of the modernisation of Denmark from the 1950s up to the 1980s and brings alive all the small fantastic stories and psychological dramas that are enacted by the large character gallery of mad people, artists, rebels, terrorists, housewives, old spinsters, nouveaux riches, immigrants and children. Kirsten Thorup attempts to develop a network of narrative in which the realism of the depiction of Lille Jonna's early years on Funen and her path out into the work also overlaps with fantastic tales of transformation, such as the fairytale of the dry-as-dust receptionist Miss Andersen, who ends up as a prosperous brothel keeper in the wild Vesterbro district of Copenhagen, and Jasmin, the wife of the kiosk owner, who leaves reality in order to live in the fairytale as a fortune-teller on the high seas and the long country roads.

In Thorup, the outside world is not a hierarchical structure but a neverending network of surprising entrances and exits to both trivial and exotic environments.

Such a mod of thought is also to be found in the novels of Ib Michael, but here the fantastic becomes an essential foundation that the novel gradually uncovers. Michael's best novel, Vanillepigen (The vanilla girl, 1991), is the first volume of a trilogy that spins stories and situations from an everyday life in the Roskilde of the 1950s into dramatic events in the history of Denmark, distant climes and ancient Inca prophecies.

Hans-Jørgen Nielsen's novel Fodboldenglen (The football angel, 1979) must also be considered as one of the possible classics of the period. Like Kirsten Thorup, Nielsen writes in this novel about utopias that end up by collapsing. Foldboldenglen tells of how the working-class boy Frands from Amager becomes neither a football player, revolutionary hero nor grown man, but who perhaps finds a foothold in existence, in his memory and his body, by letting go of his urge to want to explain and understand himself. His 'epiphany' experience of the coherence of all things during a training run is reminiscent of transcendental experiences in Dan Turéll and Klaus Høeck, and it becomes an image of an opening in Frands' obscure life.

In prose literature, Kirsten Thorup's network realism is one of many kinds of realism in the period after 1970. Bent Vinn Nielsen's debut novel Arbejdssky (Work-shy, 1978), which deals with the dregs of society, represents new unsentimental images of reality that do not appeal to the reader's sympathetic understanding and empathy, as do those of Thorup, but confront 
the reader with grotesque, murky realities. Here, the characters go in for social and mental cheating and deception of society and each other. Vinn Nielsen, with the aid of his humour and grotesque images of body and gender, manages to place the reader in the position of an embarrassed person in the know.

Another potential canonical writer, Jakob Ejersbo, works in Nordkraft (2003) on a renewal of realism. The novel takes place in the same geography as Bent Vinn Nielsen's novel, and Ejersbo does not hold back on rhetorical or plot-related effects, although he controls them highly consciously in order to give the reader the experience of something real. The reader is in a world where coke, shit and piss drip down the pages, and where the mists of hash do not conceal the brutality. We are dealing here with a journalistic, dirty realism that works on the reader by means of its insistence on details and convincing dialogue. ${ }^{4}$

One can also include Christina Hesselholdt among the canonical prose writers between 1965 and 2015. Her narrative sequence about Camilla (Camilla and the Horse, Camilla and the rest of the company, The company settles up and Left standing on the quay, 2008-2014) reminds one of the boldness in the use of voices, angles and various kinds of text as well as the linguistic sensitivity that are to be found in the novel series of Kirsten Thorup and Vibeke Grønfeldt, but Hesselholdt's series about the town life, love relationships and globetrotting of the literary figure Camilla is far more fragmentary than the novel series of the other two. In both Thorup and Hesselholdt, however, one notes that it is the springboard both writers have in minimalism that remains important, even in the voluminous publications.

Black humour and the anecdotal in Kirsten Thorup, Dan Turéll and Svend Åge Madsen have their successor in Jens Blendstrup, whose breakthrough book Gud taler ud (God speaks out, 2004) is also a candidate for canonisation. As with many prose attempts, it is the schematic of the Bildungsroman that is the springboard for Blendstrup's narrative, which is allowed to get lost in jokes, nonsense and deep tragedy in its portrayal of a father-son relationship.

Jens Blendstrup and Christina Hesselholdt, like other new prose writers also write children's books, and even though the genre 'children's literature' is normally placed in a category of its own, it should obviously be included in any discussion of canonical works in the 1965-2015 period. Precisely here we find a completely new and artistically aware children's literature that includes a number of classics. Practically all of Ole Lund Kirkegaard's 13 children's books from Lille Virgil (Little Virgil) to Gummi-Tarzan (Rubber Tarzan) and Tippe Tophat are now part of our national heritage, and Lene Kaaberbøl, Kim

\footnotetext{
${ }^{4}$ The concept of dirty realism is presented in Michael Hemmingson's The Dirty Realism Duo. Charles Bukowski and Raymond Carver on the Aesthetics of the Ugly (Hemmingson, 2008). He emphasizes that dirty realism is the ugly discourse about modern life and the beauty of the humanly grotesque.
} 
Fupz Aakeson and Josefine Ottesen are candidates too, with an international reputation as ballast.

\subsection{THE HISTORICAL NOVEL}

The literature of the 1965-2015 period includes a number of historical novels. The genre has been popular since the early 1970s, and the present-day historical novel often has the story of a woman or a modern story of loss as its starting point. Possible candidates for canonisation could be Dorrit Willumsen's novel about Marie Tussaud, Marie (1983). The modernist motif of the reification of the body and the social and psychological marginalisation of women as the other one that Willumsen threw herself into as early as in her short stories from 1965 are used here to develop the thematic around an actual person, the waxworks owner Marie Tussaud, and her dramatic life and fate during and after the French Revolution. Dorrit Willumsen opens up her modernist thematic and narrative style towards a realistic form of narration.

Dorrit Willumsen's historical novel is only one of the many contemporary historical novels. Another strong candidate is Henrik Stangerup's historical novel Vejen til Lagoa Santa (The Road to Lagoa Santa, 1981), about the 19th century naturalist P.W. Lund, who travels to Brazil in order to do research, but ends up completely abandoning his project. Willumsen's and Stangerup's historical novels can be read respectively as a male and female history of modernity. While Stangerup's hero distances himself from the modern world and a conquering masculinity, Willumsen's heroine becomes both the victim and icon of modernity: she loses one side of herself, symbolised by a faceless boy, when she liberates herself from men and becomes a successful businesswoman.

Recent attempts at a historical novel that are possible candidates are Harald Voetmann's novel about Tycho Brahe and his aristocratic friends, Alt under solen (Everything under the sun, 2014) and Lone Hørslev's Dyrets år (The year of the beast, 2014) about Marie Grubbe, who was the heroine of J.P. Jacobsen's famous novel Fru Marie Grubbe (Maria Grubbe. A Lady of the Seventeenth Century, 1876). Both authors work in different ways by allowing their narrative to be enacted at the level of the body and linking up with the sensuality of Johannes V. Jensen's famous Kongens fald (The Fall of the King, 1901).

\subsection{POST-COLONIAL NOVEL-WRITING}

Stangerup's novel was one of the biggest reader success of the age and has been translated in a number of other languages. The greatest international success of the period, however, was Peter Høeg's Frøken Smillas fornemmelse for sne (Miss Smilla's feeling for snow, 1992), which, in the form of the 
crime genre, combines a post-colonial critique of Greenland's fate under Danish hegemony with a gripping account of unscrupulous science that enriches itself and destroys natural resources. The novel impressively allows various philosophical, scientific and journalistic discourses to mingle and, in its title figure, Smilla, present a both combative, attractive and tough heroine who has taught herself hoe to find a way in and out of cultures, families and landscapes. Peter Høeg's novel positioned itself strikingly in the postcolonial tendency in international literature and could be interpreted as what the Norwegian professor of literature Arne Melberg has called a new prose, in which the factual and the fictional draw closer to each other, cf. Melberg (2008).

The writer Kim Leine, who was born in Norway, also deals with a Greenland post-colonial thematic in his writing. His prize-winning Profeterne $i$ Evighedsfjorden (The Prophets of Eternal Fjord, 2012) takes place in the 18th century and tells of a young Norwegian clergyman who comes to Greenland as part of the colonisation process, and who is shocked by his encounter with the nature and population of the country. Leine works with a narrative realism and also with characteristics taken from the Bildungsroman, but he opens up the genre as regards both action and chronology.

Danish literature acquires a post-colonial trend in the period after 1965, with the new conflicts and wars in Europe and in Iraq and Afghanistan also having become literary material in Danish literature. A possible potential classic is Jens-Martin Eriksen's novel Vinter ved daggry (Winter at dawn, 1997), which in a minimalist narrative depicts ethnic cleansing during a conflict that reminds the reason of the Balkan wars of the 1990s. A young soldier who had imagined he would help with assignments in the army ends up by taking part in a massacre of civilians. The novel opens up a new world of motifs in contemporary literature, and it provokes the reader with its lowkey account of events that call for screams, tears, horror and vociferous protest.

\subsection{EXISTENTIAL REALISM AND EXPERIMENTAL PROSE}

The critics often call for the great Danish contemporary novel. In the period up to Ejerbo's debut in 2003, many complained that the prose was too narrow and enclosed. But the contemporary novel - also in a more traditional form - has returned, and around the turn of the millennium, a traditional, narrative, psychological realism assumes an important position in the literary picture. There are many canonical candidates here, but Ida Jessen's novel Det første jeg tanker på (The first thing on my mind, 2006), immediately commands attention as an extremely well-written work that has connections 
to such existence-psychological novel writers as Tage Skou-Hansen, Martin A. Hansen and H.C. Branner. People, environments, relations, self-deception and deception are gradually uncovered and the credibility of the narrator and the characters dealt with. People are perhaps also the stories with which they do not identify themselves, seen from Jessen's standpoint at any rate.

A more experimental prose writer is Lars Frost, whose welfare trilogy opens with the novel Smukke biler efter krigen (Beautiful cars after the war, 2004), with the subtitle 'en knaldroman' (a pulp novel). The novel is a realistic narrative about a young man's journey to Iceland and his experiences inside and outside the welfare system, but the effects used are exaggerations and digressions, which give the work a parodying dimension.

The new, strong existential realism is thus also present with a number of prose works that continue the experiments of the 1970s. Pablo Llambías' Rådhus (Town Hall, 1997) consists of text pieces in various genres and photos of Danish town halls, and the various tracks of the work taken together form a socially critical prose that questions the ideas and values of the welfare state. Rådhus is an artistic critique of the consensus culture of the established welfare society, of social roles and the placing of art in a decorative, harmless position as a town-hall sculpture. And the text pointed outside the form of the book, since it was part of the installation Fri kommune (Free municipality), which was Llambías' final-exam project from the Academy of Fine Arts, where he invited the public to take part in the establishing of a new municipality and take on various assignments and functions. Rådhus tells readers about the project and thereby establishes a close relation between the empirical author and the Rådhus narrator, the publication becoming an example of performative biographism which, spearheaded by Suzanne Brøgger, is developing throughout the period.

One of Pablo Llambías' publications is a rewriting of Suzanne Brøgger's essays Karlighedens veje og vildveje (Love's paths and pitfalls, 1975). Llambías subjects the work to a kind of conversion, since he himself appears on the front page as a drag-queen and in general replaces 'she' with 'he' and 'man' with 'woman', and also adds various pieces of text to the book. Llambías' version, which appears in 2009, is a tribute to Brøgger's gender critique and her use of her own person and life in her prose as well as being a continuation of the gender critique that she created in the early 1970s. Llambías' rewriting helps to point out the qualities of the Brøgger collection: the use of various genres, the biographical play and the discussion of emancipation. Llambías underlines Brøgger's status as a classic writer and brings out the artistic qualities of the book, and the tradition of literature about gender, class and ethnicity it opens up - one which later comes to include texts by Maja Lee Langvad, Christina Nya Glaffey and Eva Tind. 


\subsection{SHORT-STORY CLASSICS}

At the turn of the millennium the short-story genre also seems capable of providing a number of potential classics. Jan Sonnergaard's short stories in Radiator were almost blitz-canonised when published in 1997. Rough, 'dirty' realism was present at full throttle in Sonnergaard. And his debut short stories became the first volume of a trilogy of stories about the top and bottom of society.'

The short story and short prose works, in the period from 1965 to 2015, enter into a kind of experimentarium and a writing away in a interlacing of genres in which the prose thematises its genre relation. In this renewal various publications have a strong position: Helle Helle's Biler og dyr (Cars and animals, 2000), Pia Juul's Mit forfardelige ansigt (My terrible face, 2001), Katrine Marie Guldager's Copenhagen (2004) and Naja Marie Aidts collection of short stories Bavian (Baboon, 2006). While the traditional short story focuses on an unheard-of event that has taken place, it is often metaphors, dialogue or a linguistic turn that govern the action and progression in the story. The event is placed in the background of the action. Helle Helle almost manages to get a whole short story and a character out of a recipe for pickled marrow and the expression 'by rule of thumb' in the short story 'Syltning' (Pickling) from Biler og dyr, while Katrine Marie Guldager lets food metaphors form the progression around a couple of the emotionally deprived persons in the narrative circle Copenhagen. 'His thoughts are like whipped egg-whites' it says about a man who finds his old mother dead in her bed as a victim of a violent assault. The metaphor says something about the 'whipped-up' and bound relationship between the mother and the man, who has indirectly brought about the assault and the break-in by talking about his lonely old mother in a bar close by.

In Pia Juul, several of the short stories have to do with how persons relate themselves and their world, and how fiction arises in the dialogue itself, as in the short story 'Den dag kogekonen kom' (The day the cook came), where an adolescent girl discovers that she can tell stories that take the wind out of the sails of the stupid boys. Here it is not in infidelity of the washerwoman that is the real event of the short story, but the discovery by the girl of her ability to tell stories. The collection is full of the mixture of horror, a strange, knowing naivety and chuckling humour that is the distinctive quality of Pia Juul's writing, most recently in evidence in the collection of poems and texts Avuncular (2014), which consists of texts, poems and short prose works, all of which have to do with something 'avuncular'.

Naja Marie Aidt works with the event-centred short story in the collection Bavian, which won the Nordic Council Literature Prize and that has been wellreceived in USA. The event often takes place at the beginning or end of the 
story, and it becomes clear that the event of the story is linked to points of view. The event is an event because it is seen and perceived as such by a character, cf. Klujeff (2002:23 ff). The little girl who becomes a laughing stock for her father and her friend because she adopts the same posture as the two adults, experiences the event as a defining experience that will probably never disappear from her life, whilst it is a mere bagatelle for the adults. In the short story 'Solbær' (Blackcurrant), the reader only understands at the end of the story what event the two women are circling round and that determines the nature of their being together - the discovery by one of the women that she is pregnant. Here a large, raw chicken that is never prepared and ends up in the refuse pail is a powerful metaphor of her unwanted pregnancy.

\section{NEGOTIATIONS AND NEW DIRECTIONS}

The positioning and importance of literature in modern society is not fixed. It emerges through constant negotiation within the literary environments, on the basis of political frameworks and ideas about culture. The expansion of the language, thematics, functions and media of literary works and texts brought about by the modern breakthrough has opened up literature in relation to culture and society, and literature finds itself in one of the hotspots of the globalised world, when the writers fight for free speech and react critically to all kinds of authorities, including themselves. Literature is no longer one thing but many things. Its borders are becoming fuzzy and its function is being questioned.

In the literary debate, it is often said, with more or less a resigned frown, that literature has lost its status and importance as a preferred form of perception in the welfare society, cf. Nielsen (2009), and that Danish literature, like the Danish language, is losing ground. The question is, however, if modern literature has ever had an unambiguous position and authority in relation to society. A number of texts and works have been canonised in the modern education system and have been interpreted as promoting personal development and awareness. Various writers have become authorities in the public debate and have been both praised and contested as such. We have seen texts and works that have created a public debate about culture and society and led to changes; certain publications have been little more that money-spinning flashes in the pan, while others have led a more obscure life in various half-public and fully public literary and cultural fora and have been made use of in many contexts: as entertainment, realisation, provocation or a meaningful interpretation of existence. 
The motley nature of literature makes it more important than ever to point to literary quality and to the many breaks that take place in relation to the preferred genres of the existing canons: the Bildungsroman, the classical short story and mainstream poetry.

Literature in the 1965-2015 period shows that literature can be a cathedral hall, an ethical challenge, a porno shop, bel canto, a frightfully ugly and grim narrative, a tear-jerker, a spiritual guide and a trenchant critique of society - and even be all of this at one and the same time.

\section{REFERENCES}

Andersen, J. E. (2005). Tid? Peter Seebergs Ved havet. In: M. Davidsen, J. Aabenhus, A.-M. Mai, (eds.), Peter Seeberg \& Hald: At åbne arkivet. (pp. 38-64). Odense: University Press of Southern Denmark,.

Auken, S., Skriver, S. (2011). Dét, der forsvinder, tager jeg med. Søren Ulrik Thomsens poesi og poetik. Copenhagen: Spring.

Bredsdorff, T. (2006). Kulturkanon, Jyllands-Posten, 28.01.2006.

Fibiger, J. (2006). Kampen om litteraturhistorien - om veje ind i og ud af litteraturen. Bogens

Verden 4, http://wayback01.kb.dk/wayback/20100504122136/http://www2.kb.dk/guests/natl/db/ bv/04/6/index1.htm (access 27.01.2015)

Foucault, M. (1969/1977). What Is an Author. In: D.F. Bouchard (ed.). Foucault. Language, Counter-Memory. Selected Essays and Interviews. Ithaca: Cornell University Press.

Gemzøe, A. (1997). Metamorfoser i mellemtiden. Studier i Svend Åge Madsens forfatterskab 1962-1986. Aalborg: Medusa.

Hansen, A. (2013). Grundlæggende befinder jeg mig bedst uden for rammen og vil blive dér Interview with Mikkel Thykier. Information, 10.01.2013.

Hemmingson, M. (2008). The Dirty Realism Duo. Charles Bukowski and Raymond Carver on the Aesthetics of the Ugly. Los Angeles: Borgo Press.

Klujeff, M. L. (2002). Novellen. Copenhagen: Gads Forlag.

Larsen, P. S. (2009). Drømme og dialoger. To poetiske traditioner omkring 2000. Odense: University Press of Southern Denmark.

Mai, A.-M. (1994). PerHøjholt: Min hånd 66. In: P. Schmidt (ed.): Laesninger i dansk litteratur, vol. 4. (pp. 229-245). Odense: Odense University Press.

Mai, A.-M. (2000-2001). Danske digtere i det 20. århundrede, vols. I-III. Gylling: Gads Forlag.

Mai, A.-M. (2010-2011). Hvor litteraturen finder sted, vols. I-III. Gylling: Gyldendal.

Mai, A.-M., Borup, A.(eds.). (1999). Historier om nyere nordisk kunst og litteratur. Gylling: Gads Forlag.

Mikkelsen, B. (2006). Badutspring om den rigtige kulturkanon. Politiken, 21.01.2006

Melberg, A. (2008). Aesthetics of Prose. Oslo Academic Press, Unipub Norway.

Nielsen, J. Ø. (2009). Kritikken som litteraritet og særegen litteraturform - om anmelderi og litteraturkriti'. StandArt, no. 2, 2009. Aarhus: Aarhus University.

Ringgaard, D. (2005). Nordbrandt. Aarhus: Aarhus University Press.

Thomsen, M. R. (2003). Kanoniske konstellationer. Odense: University Press of Southern Denmark.

Thomsen, M. R.(ed.). (2006). Passage 56. Kirsten Thorup. Aarhus: Aarhus University Press. 


\title{
WEBSITES (27.01.2015)
}

Educational Canon: Dansk litteraturs kanon: http://pub.uvm.dk/2004/kanon/ Cultural Canon: http://www.kulturkanon.dk/

\author{
Anne-Marie Mai \\ University of Southern Denmark \\ Institute for the Study of Culture \\ Campusvej 55 \\ 5230 Odense M \\ Denmark \\ ammai@sdu.dk
}


